\title{
An adenovirus early region 4 gene product is required for induction of the infection-specific form of cellular E2F activity
}

\author{
Stephen Hardy, ${ }^{1}$ Daniel A. Engel, and Thomas Shenk ${ }^{2}$ \\ Howard Hughes Medical Institute, Department of Biology, Princeton University, Princeton, New Jersey 08544 USA
}

\begin{abstract}
E2F is a cellular, sequence-specific DNA-binding factor that binds to pairs of sites that occur upstream of the E1A and E2 early mRNA cap sites. During adenovirus infection, there is induction of a form of E2F that binds cooperatively to the pair of sites in the E2 control region. Production of the infection-specific E2F activity is dependent on early region 4 (E4), as extracts of cells infected with a mutant that lacks E4 did not contain this activity. Instead, two new forms of E2F were seen with the E4 mutant. Infection with mutant viruses unable to make E1A gene products produced the wild-type infection-specific E2F activity after a delay. Mutations in the E1B-55 kD-, E1B-21 kD-, E2-72 kD-, and E3-coding regions had no effect on production of infection-specific E2F. Analysis of cell lines confirmed the results obtained with mutant viruses. Cells that expressed E1A but not E4 genes (e.g., 293 cells) did not contain infection-specific E2F. Cell lines that expressed the E4 gene contained the activity. These observations demonstrate that $\mathrm{E} 4$ participates in the infection-induced change in E2F-binding activity. The data are consistent with E1A playing an indirect role in the process by mediating the efficient expression of $\mathrm{E} 4$ gene products which, in turn, induce the alteration in E2F activity.
\end{abstract}

[Key Words: DNA-binding protein; adenovirus; early region 4]

Received February 22, 1989; revised version accepted May 16, 1989.

E2F is a cellular DNA-binding factor whose recognition site (TTTCGCG) occurs twice upstream of both the E1A and $\mathrm{E} 2$ early transcriptional start sites in the adenovirus type 2 and type 5 (Ad2 and Ad5) chromosome (Kovesdi et al. 1986, 1987). E2F activity can be detected readily in extracts of uninfected HeLa cells by DNA bandshift analysis using a single E2F site as a probe. Multiple forms are detected by this assay. The pattern of complexes observed in a bandshift assay is altered by adenovirus infection (S. Hardy and T. Shenk, in prep.). A different result is obtained when E2F activity is assayed by bandshift analysis using a probe DNA that contains the two recognition sites upstream of the adenovirus E2 early transcriptional start site. On this probe very little E2F activity is evident in uninfected cells and a substantial induction of binding activity occurs within infected cells (Kovesdi et al. 1986; S. Hardy and T. Shenk, in prep.). The induction of E2F binding observed using the E2 double recognition site DNA results from an infection-induced alteration in E2F-binding activity. E2F from infected cells binds cooperatively to the E2 substrate DNA (S. Hardy and T. Shenk, in prep.). Coopera-

1Present address: Department of Microbiology and Immunology, University of California, San Francisco, California 94143 USA.

${ }^{2}$ Corresponding author. tive binding is inhibited if the relative orientation or spacing of E2F recognition sites on E2 DNA is altered. The induction of cooperative binding probably results from the modification of preexisting E2F activity rather than synthesis of a new factor, as E2F activities from uninfected and infected cells display similar physical properties (S. Hardy and T. Shenk, in prep.).

In this paper we demonstrate that an Ad5 early region 4 (E4) gene product is required to produce the infectionspecific form of E2F. The E4 transcription unit of Ad5 encodes a set of alternatively spliced mRNAs expressed in an ElA-dependent manner at early times after adenovirus infection. The nucleotide sequence of the closely related Ad2 reveals seven translational open reading frames (ORFs) (Herisse et al. 1981; Freyer et al. 1984). Viral mutants containing large deletions in E4 are compromised for viral DNA replication, accumulation of late viral mRNAs and proteins, host cell shutoff, and viral growth (Halbert et al. 1985; Weinberg and Ketner 1986; Hemstrom et al. 1988; Bridge and Ketner 1989). Several proteins encoded by the $\mathrm{E} 4$ gene have been identified, although their exact functions are not known. One of these, a $34-\mathrm{kD}$ protein, has been shown to be associated physically during infection with a $55-\mathrm{kD}$ protein encoded by the adenovirus E1B gene (Sarnow et al. 1984). 
Infection with a mutant virus lacking the E4 gene failed to generate E2F activity with the binding properties of the activity isolated from wild-type Ad5-infected cells. Infection with viruses unable to produce E1A gene products generated the infection-specific form of E2F after a delay, demonstrating that E1A products are not required to produce the infection-specific form, and suggesting that their role in the process is to activate the E4 gene transcriptionally. Consistent with this interpretation, cells that contain and express the E1A but not the E4 gene did not contain the infection-specific form of E2F, whereas cells that contained both viral genes expressed infection-specific E2F. Finally, undifferentiated F9 teratocarcinoma cells were found to contain an E2Flike activity that exhibited properties different than those of the factor from Ad5-infected HeLa cells.

\section{Results}

\section{Accumulation of modified E2F activity after infection} with Ad5

We have shown previously that E2F activity can be detected readily in extracts of uninfected HeLa cells by DNA bandshift analysis and that uninfected cell activity can be distinguished from Ad5-infected cell activity in these assays (S. Hardy and T. Shenk, in prep.). Uninfected cell extracts generated four specific shifted bands using a probe DNA containing a single E2F site. These complexes resulted from sequence-specific DNA binding, as demonstrated by competition experiments. The data argue strongly that the complexes were E2Fspecific, because four different 30 -bp probe DNAs, related only by their E2F recognition sites, generated the same set of complexes, and complex formation was not detected when any one of the four ${ }^{32} \mathrm{P}$-labeled probe DNAs was assayed in the presence of any of the other DNAs included as an unlabeled competitor (S. Hardy and T. Shenk, in prep.). Infected cells produced an altered pattern of E2F-specific complexes on single-site probe DNAs; one of the complexes formed in the presence of uninfected cell extract was replaced by a new complex. Uninfected and infected cell extracts also were readily distinguished in bandshift assays that used a probe DNA containing two E2F sites in the configuration in which they occur upstream of the E2 transcriptional start site. Whereas infected cell E2F generated very little complex on this DNA, a dramatic induction in complex formation occurred in Ad5-infected nuclear extracts. The complex (a doublet of bands) was shown to contain two occupied E2F sites by DNA footprint analysis and was demonstrated to be E2F-specific by competition with an unlabeled DNA containing a single E2F recognition site from the region upstream of the E1A cap site (S. Hardy and T. Shenk, in prep.).

Using the bandshift assay to distinguish different E2F activities, the appearance of the infection-specific form of E2F was monitored as a function of time after infection with wild-type virus (Fig. 1). Two ${ }^{32}$ P-labeled probe DNAs were used. E1A site I DNA contained a single E2F recognition site derived from the region upstream of the
E1A unit, and E2 DNA contained the two E2F sites derived from the region upstream of the E2 early unit (Fig. 1A).

The E1A site I DNA probe generated the expected E2F-specific complexes (E2F-a, E2F-b, E2F-c, E2F-d) in uninfected cell extracts (Fig. 1B, O-hr lane). As the infection progressed, a new E2F-specific complex (E2F-e) came to predominate. It was first detectable at $6 \mathrm{hr}$ and reached maximal levels at $12 \mathrm{hr}$ after infection. Initially, the activity of E2F-c increased; after $10 \mathrm{hr}$ its level decreased as E2F-e increased, suggesting that there could be a precursor-product relationship between the E2F species present in these complexes. The amount of E2F-a complex also dropped, but the level of this complex has proved to be highly variable from extract to extract, and its level is not correlated with infection (data not shown|. The overall amount of E2F-binding activity increased severalfold as the infection progressed. This increase is difficult to quantify, because the cells change dramatically as a result of Ad5 infection. However, it probably reflects a genuine increase in the total amount of E2F, as we tested five other DNA-binding activities and found that none of these increased (data not shown).

Specific complexes barely were detectable when E2F from uninfected cell extracts was assayed on the E2 double-site DNA (Fig. 1C, 0-hr lane). As the infection proceeded, substantial quantities of an E2F activity accumulated that generated a slowly migrating doublet of shifted bands, termed E2F-Ad. As described above, the E2F-Ad complex contains two occupied E2F-binding sites. E2F-Ad first was detected at $4 \mathrm{hr}$ and reached maximal levels at $12 \mathrm{hr}$ after infection. Two less abundant, more rapidly migrating bands /designated by arrowheads) were generated also on the E2 probe DNA (Fig. 1C). These bands represent complexes in which only one of the two E2F-binding sites on the probe DNA was occupied (S. Hardy and T. Shenk, in prep.).

The E2F activities giving rise to the E2F-e complex on the E1A site I probe and the E2F-Ad complex on the E2 probe first were detected at about the same time after infection $(4-6 \mathrm{hr})$ and simultaneously reached peak levels at $12 \mathrm{hr}$. This suggested that the same infected cell E2F activity might form both complexes. This is probable, as the E2F activities giving rise to the two complexes copurified through two sequential high-resolution chromatographic steps (S. Hardy and T. Shenk, in prep.).

An Ad5 E4 gene product is essential for generation of the infection-specific form of E2F

It has been suggested (e.g., Kovesdi et al. 1986, 1987) that the infection-specific induction of E2F activity was mediated either directly or indirectly by an ElA gene product, given the fact that $\mathrm{E} 2 \mathrm{~F}$ binds to a control region activated by E1A (Kovesdi et al. 1987). However, the infection-specific form of E2F did not accumulate to detectable levels until 4-6 hr after infection (Fig. 1), a time when early viral genes were expressed actively /data not shown). This suggests that another early gene product 


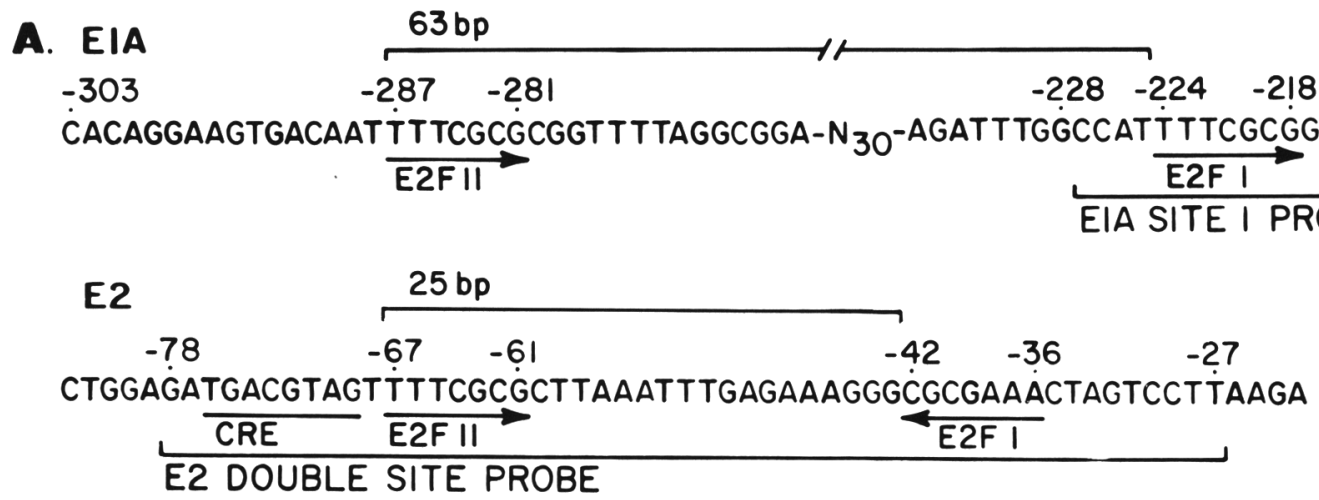

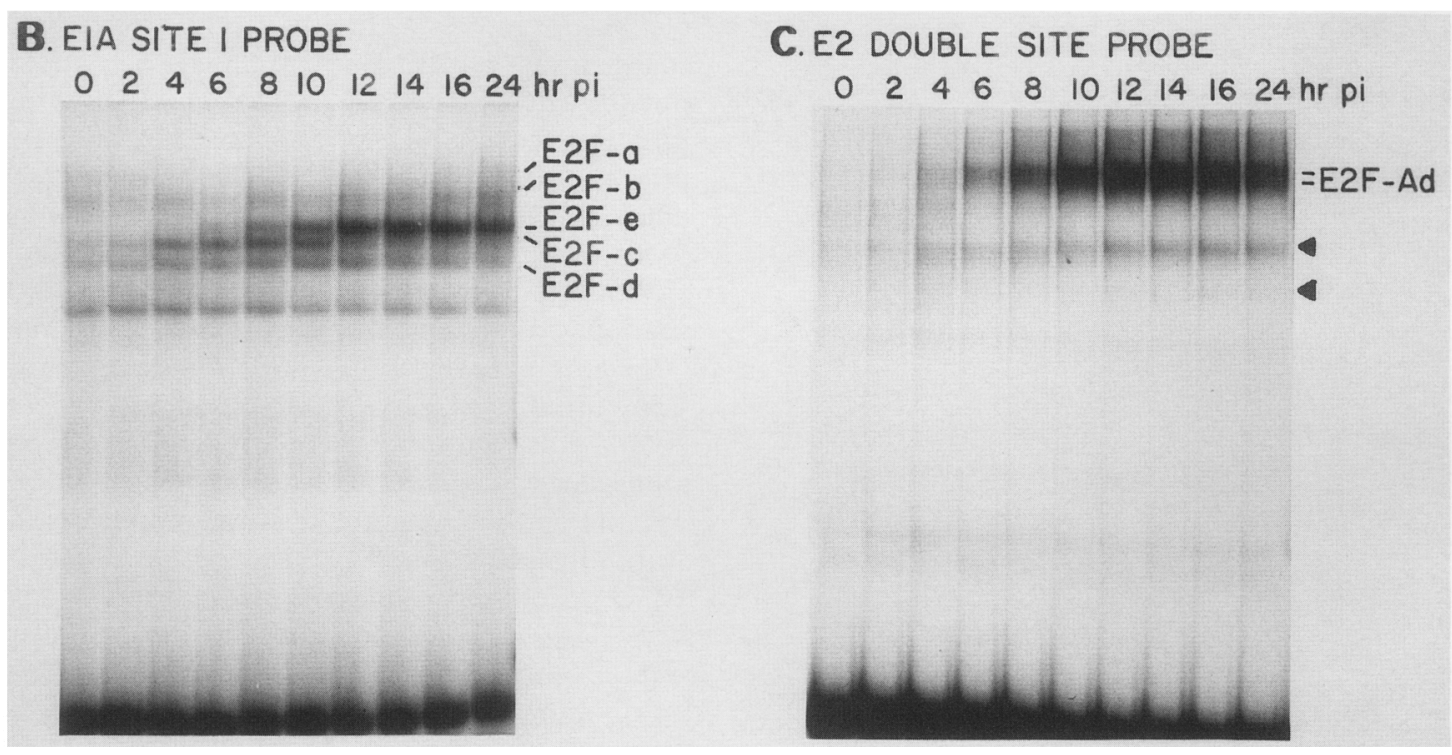

Figure 1. Sequences of probe DNAs and bandshift analysis of E2F activities that accumulate during Ad5 infection. $(A)$ The nucleotide sequences of regions upstream of the E1A and E2 early transcriptional start sites are presented. Numbers above the sequence mark positions relative to the mRNA cap sites at +1 . Brackets above the sequence measure the distance between E2F recognition sites, which are designated by arrows below the sequence. Brackets below the sequence localize the DNA segments employed as probe DNAs throughout this paper. $(B)$ DNA bandshift analysis of nuclear extracts prepared at various times postinfection (hr pi) using ${ }^{32} \mathrm{P}-$-labeled E1A site I DNA as probe. E2F-specific complexes are labeled E2F-a, E2F-b, E2F-e, E2F-c, and E2F-d. Unlabeled bands are not E2F-specific. $(C)$ The same extracts as described for $B$ were analyzed using ${ }^{32} \mathrm{P}$-labeled E2 double-site DNA as probe. The double-site occupancy complexes are labeled E2F-Ad and single-site occupancy complexes are designated by arrowheads.

apart from E1A products might play a role in the modification of E2F activity.

Accordingly, nuclear extracts were prepared from cells infected with mutant adenoviruses that failed to express products of the E1B, E2, E3, or E4 genes and were assayed for the ability to generate the infection-specific E2F-e and E2F-Ad complexes (Fig. 2). Extracts of cells infected for either 12 or $24 \mathrm{hr}$ with the E4 mutant $d 1366$ failed to produce the E2F-e complex when assayed on the ElA site I probe (Fig. 2A). All of the other mutants induced accumulation of the E2F-e complex. When the same extracts were assayed for production of the E2F-Ad complex using the E2 probe, all of the mutants, including dl366, proved to generate a complex migrating at the position of the infected cell-specific doublet /Fig. 2B). There were two subtle differences in the dl366 assay. First, the complex running at the position of E2F-Ad appeared to form a single band rather than the characteristic doublet. Second, either a new complex or increased amounts of a complex generated normally with uninfected cell extracts was evident (arrowhead, Fig. 2B). Both of these bands represented E2F-specific complexes, as their formation was competed by inclusion of excess, unlabeled ElA site I DNA in the binding reaction (data not shown). To evaluate the complexes formed on E2 DNA by activities in the dl366 extract, a bandshift analysis was performed using a polyacrylamide gel with altered cross-linking (bis-acrylamide: acrylamide :: $1: 60$, instead of the standard $1: 20$ ) (Fig. $2 C)$. In this gel, none of the d1366-specific complexes comigrated with the E2F-Ad complex.

To confirm that the infection-specific E2F activity in dl366-infected cells was different from that in cells infected with wild-type virus, extracts were prepared at 24 $\mathrm{hr}$ after infection with wild-type or mutant viruses and subjected to chromatography on a cation exchange ma- 


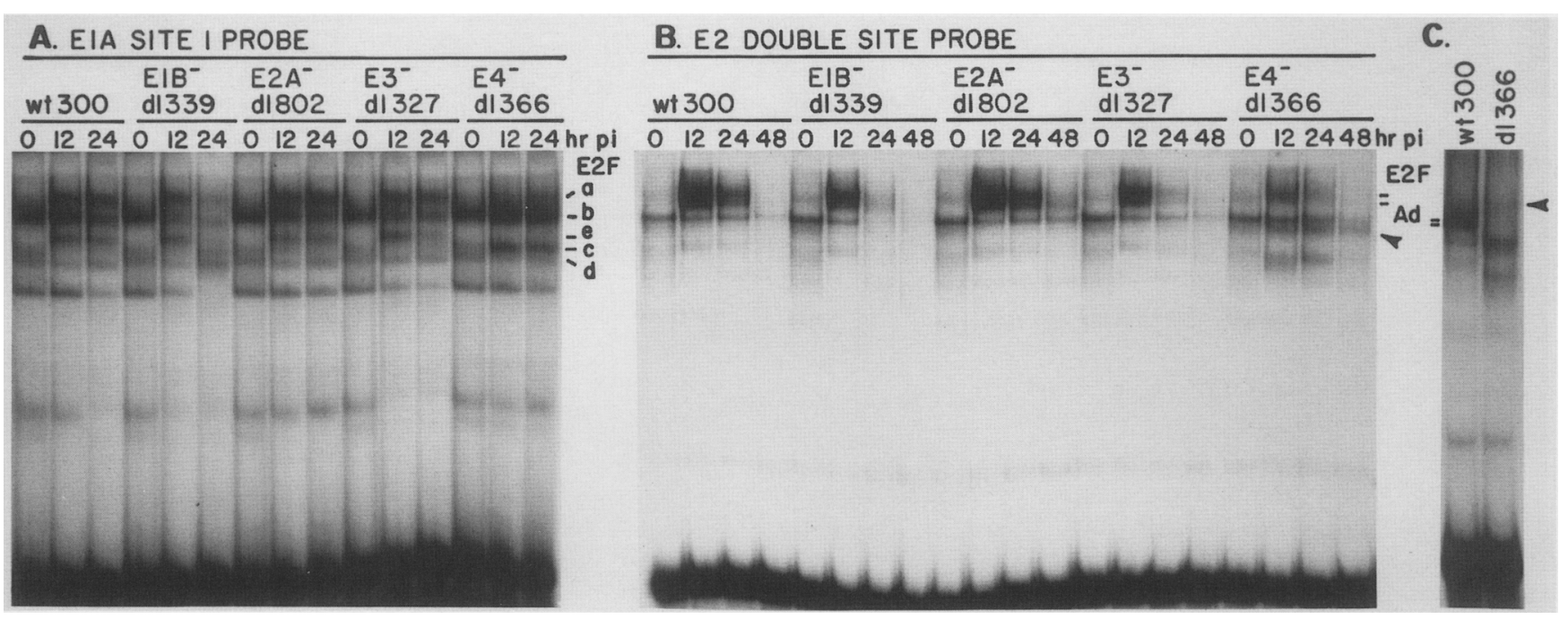

Figure 2. DNA bandshift analysis of E2F activities in nuclear extracts prepared at various times after infection with wild-type and mutant adenoviruses. (A) Assays were performed using ${ }^{32}$ P-labeled E1A site I DNA as probe with extracts prepared at 0,12, or 24 hr postinfection (hr pi) with the indicated viruses. E2F-specific complexes are labeled E2F-a, - b, -e, -c, and -d. Unlabeled bands are not E2F-specific. $(B)$ Assays were performed using ${ }^{32}$ P-labeled E2 double-site DNA as probe with the same extracts as described for $A$. Electrophoresis was carried out using a $4 \%$ polyacrylamide gel (acrylamide : bis-acrylamide :: $1: 20$ ). The double-site occupancy E2FAd complex is labeled, and a complex specific to dl366-infected cells is marked by an arrowhead. Unlabeled bands are either singlesite occupancy complexes of E2F on the probe DNA or nonspecific complexes. (C) The wt300 and dl366 24-hr samples from $B$ were subjected to electrophoresis in a $4 \%$ polyacrylamide gel with altered cross-linking (acrylamide : bis-acrylamide : : $1: 60$ ). Labels are as in $B$.

trix (SP-5PW). Then the fractions were assayed for E2F activities by bandshift assay (Fig. 3). Analysis using the ElA site I probe (Fig. $3 \mathrm{~A}, \mathrm{C}$ ) revealed that the activities giving rise to the E2F-a and E2F-b complexes (fractions 5-8) were separated from those producing the E2F-c, E2F-d, and E2F-e complexes (fractions 8-13). The dl366 profile (Fig. 3C) contained an E2F-specific complex that comigrated with the E2F-b complex in the electrophoretic bandshift analysis, but the E2F activity responsible for the complex eluted from the matrix at a higher salt concentration than that producing E2F-b, copurifying with the activity that generated the E2F-C and E2F-d complexes (fractions 8-13). The activity generating this complex was either unique to dl366-infected cells or present at higher levels in mutant than wild-typevirus-infected cells. The complex was not detected in Figure $2 \mathrm{~B}$, as it was obscured by the normal E2F-b complex. Analysis using the E2 probe (Fig. 3B,D) demonstrated that the activity giving rise to the E2F-Ad complex (Fig. 3B, fractions 8-13) coeluted with the factor producing the E2F-c, E2F-d, and E2F-e complexes and separated from the 11366 -induced activity that generated a complex with similar electrophoretic mobility as E2FAd (Fig. 3D, upper arrowhead, fractions 5-7). The dl366induced activity whose complex migrated more rapidly than E2F-Ad coeluted with that giving rise to E2F-Ad (Fig. 3D, lower arrowhead, fractions 8-13).

In summary, d1366-infected cells clearly contain one or more E2F activities not detected in uninfected cells. However, the d1366-specific activities can be distinguished from those induced by wild-type virus both on the basis of their chromatographic behavior and the electrophoretic mobility of their complexes with probe DNAs.

\section{dl366-specific E2F activity exhibits a shorter bound} lifetime on E2 DNA than does wt300-specific activity

Off-rate analysis of E2F complexes performed with unfractionated extracts demonstrates a major difference between infected and uninfected cell extracts. The infected cell extract produces complexes with a long bound lifetime, and the uninfected extract does not (S. Hardy and T. Shenk, in prep.). The complexes formed by dl366-specific E2F were tested in an off-rate assay to determine whether they were as stable as the E2F-Ad complex. E2 DNA labeled with ${ }^{32} \mathrm{P}$ was added to extracts prepared from either wt300- or d1366-infected cell nuclei, the mixtures were incubated until E2F binding reached equilibrium (see Materials and methods), and a substantial excess of unlabeled E1A site I DNA was added. The decay rates of complexes formed between E2F activities and E2 DNA were monitored in a bandshift assay (Fig. 4A), bands representing specific complexes were quantified by densitometry, and the intensities of complexes were plotted as a function of time (Fig. 4B). As expected (S. Hardy and T. Shenk, in prep.), the E2F-Ad complex formed by the activity induced by infection with wildtype virus displayed a half-life of $>1 \mathrm{hr}$. The complexes formed on E2 DNA by d1366-specific E2F activity were considerably less stable. They exhibited half-lives of 10 


\section{Hardy et al.}

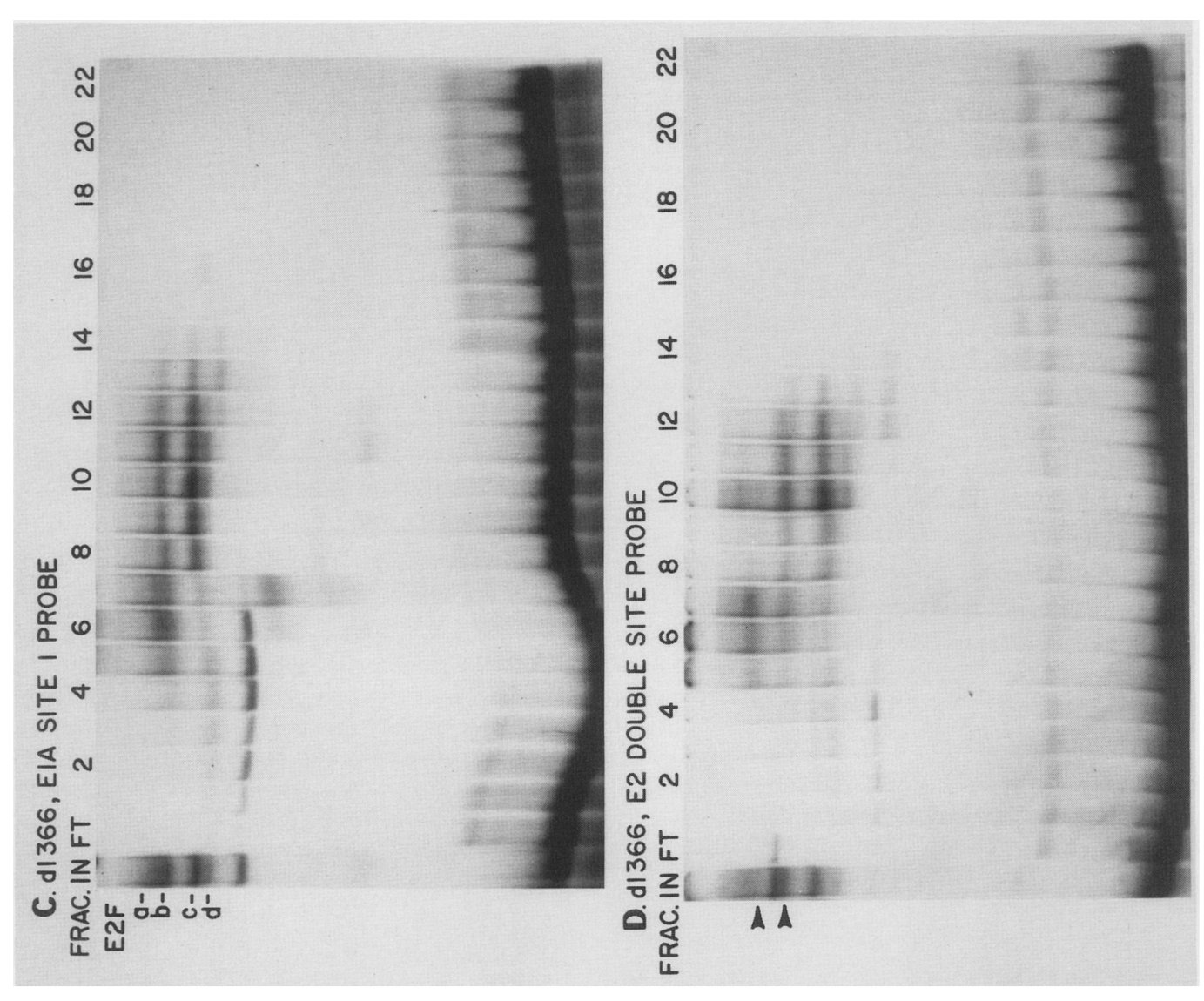

헝므 터

그응

궁

范艺志

总㤩

丞

氙吾焉

3 을

봉조

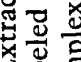

离

कृ

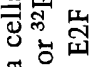

苞记

记

过

光造

훙

䆑峦

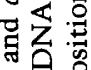

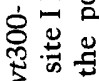

«

봉 四煤

总

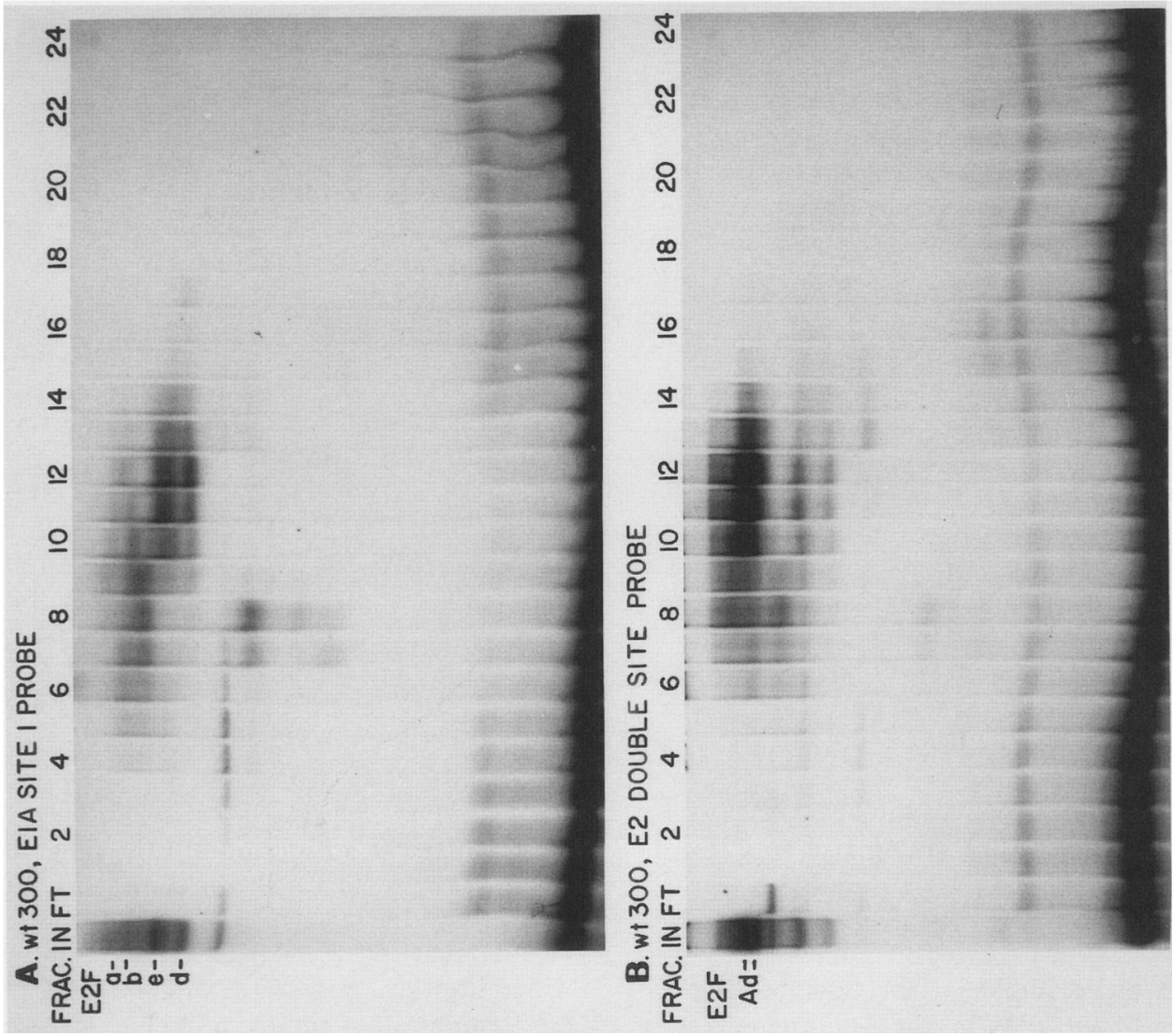

造

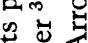

害六

我

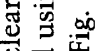

声。

可总

(⿻上丨

过

क्ष

$\exists$.

क氙

可

政

峲氜

岁究

号

शै

要

击

尝 5

कृ

은 


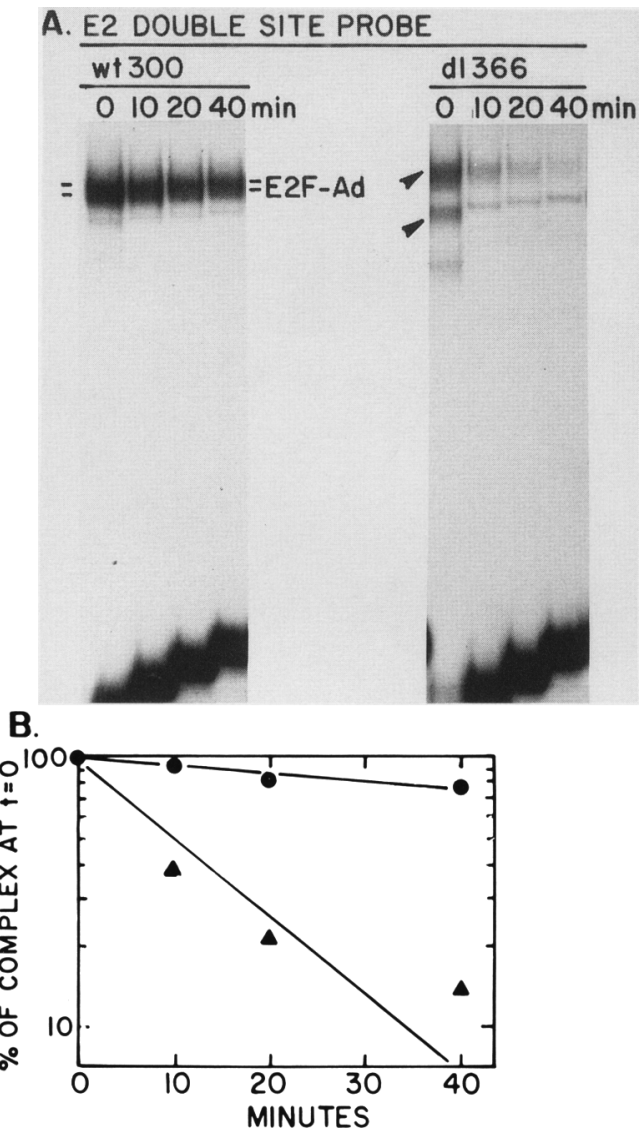

Figure 4. Off-rate analysis of E2F complexes formed by activities from wt300- and dl366-infected HeLa cells. (A) Bandshift analysis of the off-rate experiment. Complexes were formed on ${ }^{32}$ P-labeled E2 double-site DNA using extracts prepared at $24 \mathrm{hr}$ postinfection with either wild-type or mutant virus. A 500-fold molar excess of unlabeled E1A site I DNA was added, and samples were taken for electrophoretic analysis at the times after addition of competitor indicated above the lanes. Each sample was loaded in a running gel as soon as it was taken. As a result, samples were subjected to electrophoresis for somewhat different time periods, leading to small differences in the mobility of complexes and free DNA. The E2F-Ad complex is labeled and dl366-specific E2F complexes are marked by arrowheads. $(B)$ Quantitative plot of off-rate data. The intensities of bands representing E2F complexes were quantified by densitometry; the percent of complex remaining was calculated and plotted as a function of time after addition of competitor. $(\bullet)$ wt300-Specific E2F-Ad; (A) more slowly migrating dl366-specific E2F complex.

min or less. Thus, the E2F-specific complexes formed on E2 DNA by activities in dl366-, as compared to wt300infected cells, can be distinguished readily by their bound lifetimes.

Binding dependence on orientation and spacing of E2F sites: further discrimination between $\mathrm{dl} 366-$ and wt300-specific activities

Formation of the E2F-Ad double-site occupancy complex by E2F from wild-type-virus-infected cells depends on the proper spacing and orientation of the two E2F binding sites on E2 DNA (S. Hardy and T. Shenk, in prep.). This was demonstrated by assaying binding on variants of the E2 DNA in which the E2F binding sites were rearranged (Fig. 5A). The orientation of the site II core sequence was reversed without altering the spacing of the two sites on E2-INV DNA, whereas the spacing between site I and site II was increased without altering their relative orientation on $\mathrm{E} 2+5$ and $\mathrm{E} 2+10$ DNAs. The E2 +5 alteration moves site II to the opposite face of the helix relative to site I, as compared to its normal position, whereas $\mathrm{E} 2+10$ repositions the sites on their normal relative helical faces.

As found previously, wt 300 -specific E2F generated substantial quantities of the E2F-Ad complex on the E2 and E2+10 DNAs and very little of the complex on the E2-INV and E2+ 5 DNAs (Fig. 5B). Both E2F recognition sites on each of the DNAs are functional because double-occupancy complexes were formed on E2-INV and E2 +5 DNAs if the concentration of E2F activity added to the binding reactions was increased substantially (S. Hardy and T. Shenk, in prep; data not shown). Therefore, the differences between E2 DNA and the rearranged variants are indicative of an orientation and spacing dependence of wt300-specific E2F binding.

This assay was repeated using an extract containing dl366-specific E2F (Fig. 5B). Both E2F-specific complexes were formed on E2 DNA (arrowheads). Formation of the faster migrating complex was independent of orientation and spacing, whereas the slower migrating complex was dependent on these two parameters.

Thus, one of the E2F-specific complexes formed on E2 DNA by activities in dl366-infected cells exhibited dependence on orientation and spacing, but the other did not.

Ad5 E1A gene products are not required for generation of the normal infection-specific form of E2F

An E4 gene product is required for induction of normal infected cell E2F activity. This suggests that E1A products may not play a direct role in the process. To test this notion, the ability of two E1A mutants to induce the infection-specific form of E2F was examined. Nuclear extracts were prepared at various times after infection with $d 1312$ or $d 1343$ at multiplicities of $200 \mathrm{pfu} /$ cell and tested by bandshift assay for the ability to generate the E2F-e single-occupancy complex on E1A site I DNA (Fig. 6A) and the E2F-Ad double-occupancy complex on E2 DNA (Fig. 6B). Both E1A mutants generated activities capable of producing these complexes. However, the infection-specific activities did not appear until quite late after infection. Whereas E2F-e and E2F-Ad complexes were detected in assays of extracts prepared at $4-6 \mathrm{hr}$ after infection with wild-type virus (Fig. 1), the complexes were not evident in assays of extracts prepared at $24 \mathrm{hr}$ after infection with $d 1312$ or dl343. They were detected in assays of extracts prepared at 36,48 , or $72 \mathrm{hr}$ after infection with the E1A mutants. This delay is almost certainly the result of a delay in accumulation of 
Hardy et al.

A.

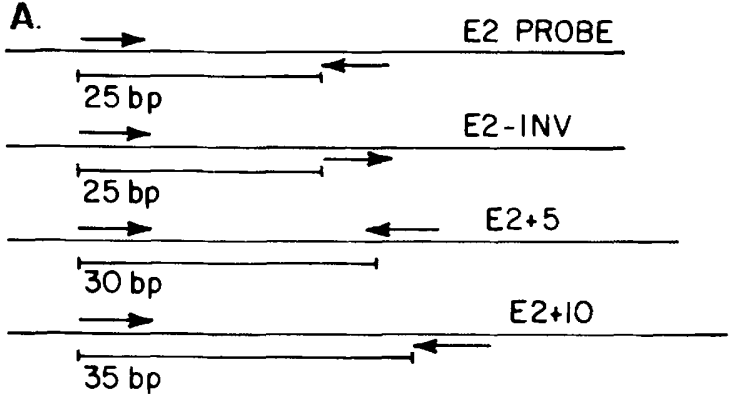

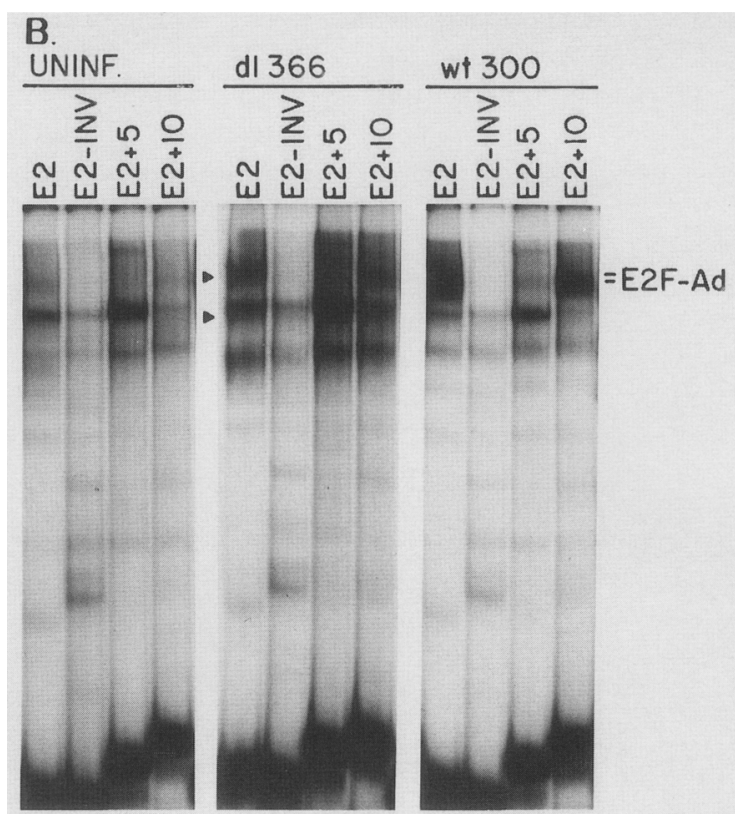

Figure 5. Assay for the dependence of E2F binding on the orientation and spacing of E2F sites in E2 DNA. (A) Diagram of the arrangement of E2F sites in E2 DNA and rearranged variant DNAs. Arrows indicate orientation of sites and the bar under each schematic indicates the spacing between sites. (B) Bandshift assay of E2F from uninfected HeLa cells or HeLa cells harvested at $24 \mathrm{hr}$ postinfection with wt 300 or dl366. Bands representing the E2F-Ad complex are labeled, and bands representing dl366-specific E2F complexes are marked by arrowheads.

E4 gene products in the absence of the E1A activation function. E4-specific RNA (quantified by RNase protection; Melton et al. 1984) accumulated at a much slower rate in $d 1343$ than in wt300-infected cells (Fig. 6C). Cells infected with wt300 contained twice as much E4 RNA at $4 \mathrm{hr}$ as was present at $24 \mathrm{hr}$ after infection with $d 1343$.

If the shifted bands generated by the E2F activity in dl343-infected cells on E2 DNA represented authentic

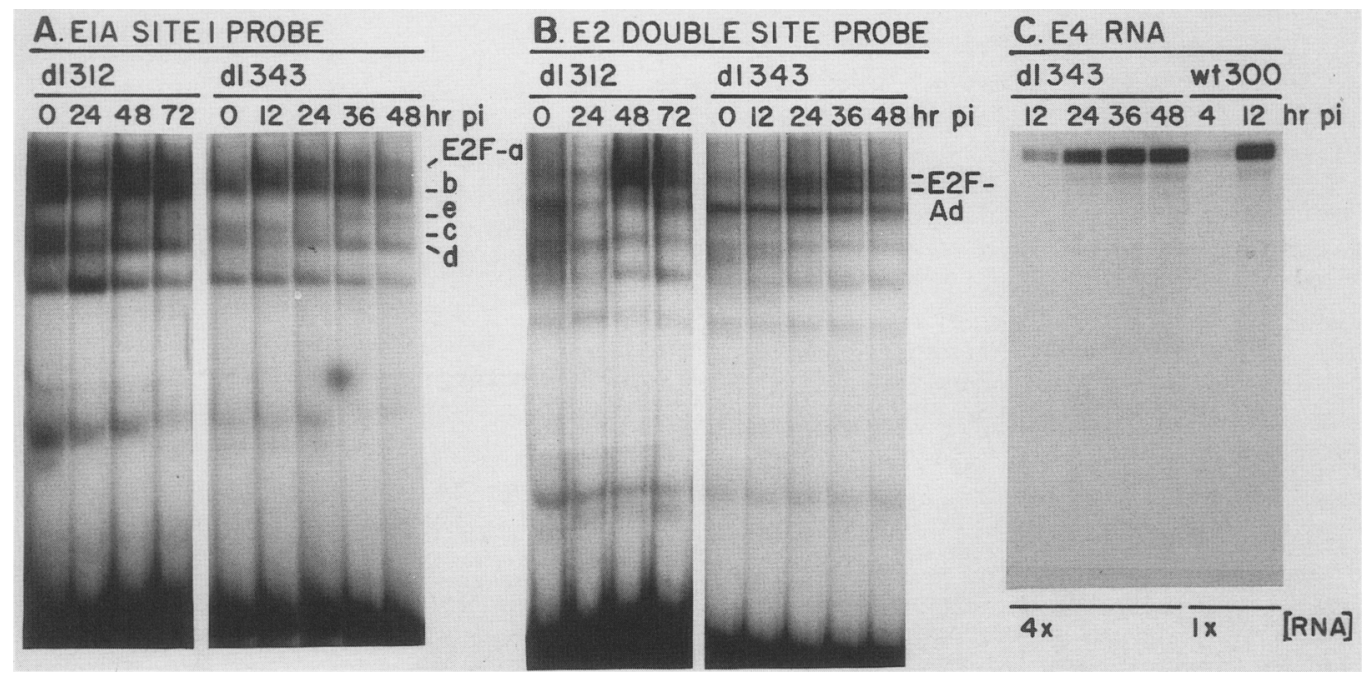

Figure 6. Analysis of E2F activities and E4-specific mRNAs produced in cells infected with mutant adenoviruses unable to express ElA products. $(A)$ Bandshift assay performed using ${ }^{32} \mathrm{P}$-labeled ElA site I DNA as probe with extracts prepared at various times postinfection (hr pi), with either dl312 or dl343 at a multiplicity of 200 pfu/cell. E2F-specific complexes are labeled E2F-a, -b, -e, -c, and $-\mathrm{d}$. $(B)$ Bandshift assay performed using ${ }^{32} \mathrm{P}$-labeled E2 double-site DNA as probe with the same extracts as described for $A$. The double-site occupancy E2F-Ad complex is labeled. Unlabeled bands are either single-site occupancy complexes of E2F on the probe DNA or nonspecific complexes. (C) RNase-protection analysis of E4-specific mRNA. Cytoplasmic RNA was prepared at the indicated times postinfection (hr pi) with either $d 1343$ (multiplicity of $200 \mathrm{pfu} / \mathrm{cell}$ ) or wt 300 (multiplicity of 20 pfu/cell). Fourfold more RNA was assayed in each mutant-virus-infected sample than in wild-type-virus-infected samples. The probe RNA corresponded to the 3 '-terminal portion of the transcription unit. 
E2F-Ad double-occupancy complex, then they should display a long bound lifetime. To test this prediction, the half-lives of complexes formed on E2 DNA by dl343. and wt300-infected cell extracts were compared. They were found to be indistinguishable (Fig. 7).

Two controls were performed to ascertain that the infection-specific E2F activity did not result from contamination of the E1A mutant virus stocks with wild-type virus. First, the virus was prepared from a portion of the cells used for the experiment shown in Figure 6C. At 96 $\mathrm{hr}$ after infection with d1343, contamination with wildtype virus was $<1$ part in $10^{6}$, the limit of the assay's sensitivity, as judged by plaque production on 293 and HeLa cells. Second, total RNA was prepared at $72 \mathrm{hr}$ after infection of HeLa cells with d1312 and examined for the presence of E1A mRNA by RNase protection assay. None was detected (data not shown).

Apart from the delay in the appearance of activities giving rise to E2F-e and E2F-Ad complexes, there was another difference between E1A mutants and other adenoviruses. The amount of E2F-e complex was consistently substantially greater than the amount of E2F-d complex generated by extracts of wt 300 (Fig. 1A), dl327, dl339, or dl802 (Fig. 2A). However, less E2F-e than E2F-d complex was produced by El A mutant extracts (Fig. 6A). It is difficult to say whether this was due to a failure to accumulate sufficient levels of E4 products in a timely fashion or to a direct effect of E1A products on the efficiency of E4 product function.

ElA gene products are not required for generation of the infection-specific form of E2F. However, the modified E2F activity only appears after a delay in the absence of ElA function, as E4 gene products accumulate very slowly under these conditions.

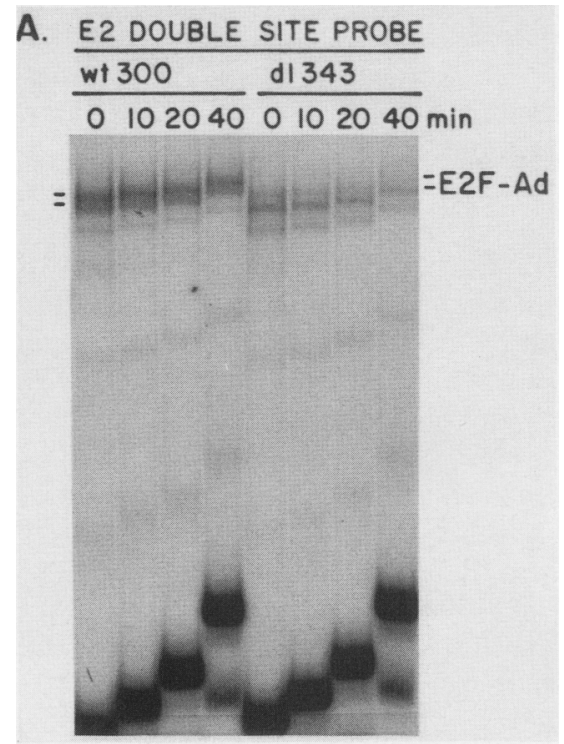

Infection-specific E2F activity in cell lines correlates with the presence of the E4 gene

The 293 (Graham et al. 1977), KB8, and KB16 cells (Babiss et al. 1983) all express the ElA gene constitutively. Nuclear extracts of these cells were prepared and tested for their ability to form the E2F-Ad complex on E2 DNA (Fig. 8). None of the extracts generated detectable levels of the complex, consistent with the essential role of an $\mathrm{E} 4$ gene product in the process.

Lewis et al. (1974) have produced a set of Ad2-transformed hamster embryo cell lines (Ad2HE cells) by infection with UV-inactivated virus. All of these cell lines express E1A, E1B, and some E4-coded mRNAs (Esche 1982). Ad2HE1 cells also express E2 mRNA and Ad2HE4 cells contain an E3 mRNA, whereas the remainder of the lines fail to produce detectable levels of E2 and E3 mRNAs. Nuclear extracts of these cell lines were tested for their ability to form the E2F-Ad complex on E2 DNA (Fig. 9A). All of the lines except Ad2HEl contained an activity that comigrated with the E2F-Ad double-occupancy complex. The extracts also were tested for their ability to generate the E2F-e single-occupancy complex on E1A site I DNA. All of the extracts, except that from Ad2HEl cells, produced this infection-specific complex (data not shown). It is not surprising that one of the E4expressing cell lines failed to produce the infection-specific E2F activity. The UV treatment could have produced a mutation in the key E4 ORF in the virus that gave rise to Ad2HE1 cells. A single Ad12 transformant (Ad12HE4) was tested also, and it did not contain infection-specific E2F activity (Fig. 9A).

The identities of the Ad2HE-specific complexes comigrating with the E2F-Ad complex were verified by mea-

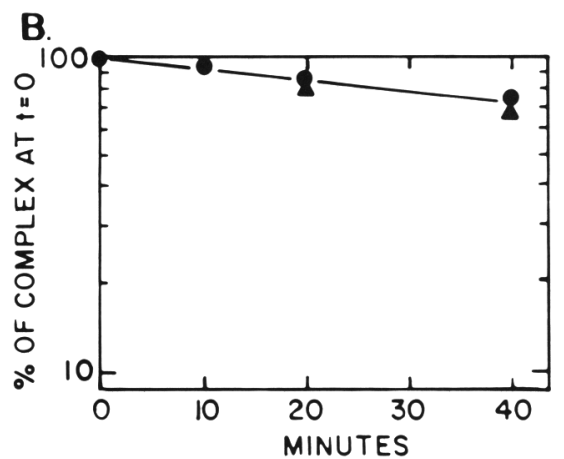

Figure 7. Off-rate analysis of E2F complexes formed by activities from wt300- and d1343-infected HeLa cells. (A) Bandshift analysis of the off-rate experiment. Complexes were formed on ${ }^{32}$ P-labeled E2 double-site DNA using extracts prepared at 24 hr after infection with wt300 (multiplicity of $20 \mathrm{pfu} / \mathrm{cell}$ ) or $48 \mathrm{hr}$ after infection with $\mathrm{dl} 343$ (multiplicity of $200 \mathrm{pfu} / \mathrm{cell}$ ). Analysis was performed as described in the legend to Fig. 4. The E2F-Ad complexes are labeled. $(B)$ Quantitative plot of off-rate data. The intensities of bands representing E2F-Ad complexes were quantified by densitometry; the percent of complex remaining was calculated and plotted as a function of time after the addition of competitor. $(\bullet)$ wt300-Specific E2F-Ad; (A) dl343-specific E2F-Ad. 


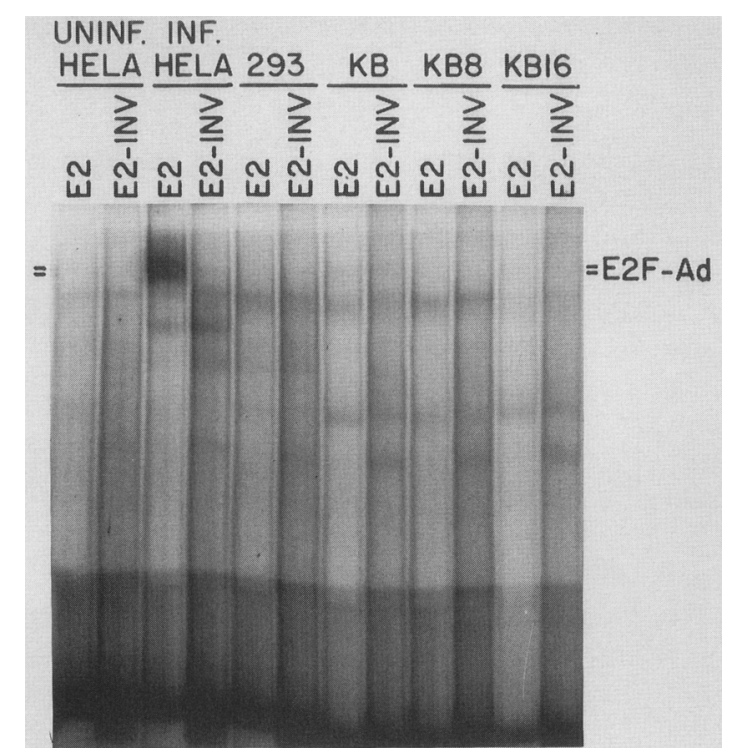

Figure 8. Assay for infection-specific E2F activity in a variety of human cell lines, some of which express the Ad5 or Ad2 E1A and/or E1B gene. Extracts were prepared from exponentially growing cells and assayed by bandshift analysis using ${ }^{32} \mathrm{P}-\mathrm{la}$ beled E2 double-site DNA or E2-INV DNA as probes. Uninfected and wt 300 -infected HeLa cell extracts were included as controls. The infection-specific E2F-Ad complex is labeled.

suring the bound lifetime of the complex formed in Ad2HE4 extracts (Fig. 9B) and the dependence of complex formation in Ad2HE2 extracts on E2F-binding site orientation and spacing (Fig. 9C). In both cases, the Ad2HE-specific complex behaved identically to that produced by extracts of Ad5-infected HeLa cells.

The Ad2HE cells clearly contain the infection-specific form of E2F. The assays do not discriminate the hamster from the human factor. In addition to further correlating this form of E2F activity with E4 gene function, its presence in continuous cell lines indicates that it can accumulate in the absence of an ongoing viral infection.

\section{F9 cells do not contain detectable infection-specific E2F activity}

The mouse F9 teratocarcinoma cell line in its undifferentiated state has been reported to contain infection-specific E2F activity (Reichel et al. 1987).

We attempted to produce such a complex in a bandshift assay using an extract of undifferentiated F9 cells and the E2 DNA as probe. Four bands were generated that could be competed by inclusion of unlabeled, homologous DNA in the binding reaction, indicating that they resulted from sequence-specific interactions (Fig. 10A). As reported by Reichel et al. (1987), one of the bands migrated similarly to the E2F-Ad double-occupancy complex, and it was produced in higher quantities in undifferentiated F9 extracts than in uninfected HeLa cell extracts. However, this band did not represent the E2F-Ad complex. It displayed a very short bound lifetime in off-rate experiments (Fig. 10B), and it did not ex- hibit a dependence on the orientation or spacing of E2Fbinding sites (Fig. 10C). Furthermore, when the F9 extract was assayed using the E1A site I DNA probe, the infection-specific E2F-e complex was not detected (data not shown).

The activity in undifferentiated F9 cells is not authentic infection-specific E2F.

\section{Discussion}

The main conclusion of this work is that an E4 gene product is required for generation of the altered E2F activity that accumulates within adenovirus-infected cells. An Ad5 mutant lacking the E4 gene, dl366, failed to induce authentic, infection-specific E2F activity. Rather, cells infected with d1366 accumulated two E2F activities that were distinguishable from either uninfected or normal infected cell activities by a variety of criteria. The dl366-specific activity that generated the more slowly migrating complex was chromatographically separable from the factor responsible for the normal infection-specific E2F-Ad complex (Fig. 3), and it gave rise to a complex that could be distinguished from E2FAd both on the basis of its slower electrophoretic mobility (Fig. 2C) and reduced stability (Fig. 4). This dl366specific complex did, however, display a clear dependence on the orientation and spacing of E2F-binding sites on E2 DNA, as is the case for normal infection-specific E2F (Fig. 5B). The dl366-induced activity that produced the more rapidly migrating complex coeluted from the SP-5PW matrix with the factor that generated the E2F-Ad complex (Fig. 3). However, this activity exhibited no binding site orientation or spacing dependence in its interaction with E2 DNA |Fig. 5B|, and it produced a complex that was less stable (Fig. 4) and migrated faster in a bandshift assay than E2F-Ad (Fig. 2C).

ElA gene products were not essential for the induction of infection-specific E2F activity. Two different E1A mutants, dl312 and d1343, generated the activity within infected cells. The electrophoretic mobility of complexes in bandshift assays (Fig. 6A,B) and the bound lifetime of E2F in the E2F-Ad complex (Fig. 7) both argued that bona fide infected cell-specific E2F was present in extracts of $d l 312$ and $d l 343$-infected cells.

The data from cell lines that harbor and express adenovirus genes fit well with the conclusions on the basis of the analysis of mutant viruses. Cells expressing E1A, E1B, and E4 genes (Fig. 9) contained the infection-specific form of E2F, whereas those expressing only E1A and ElB genes did not (Fig. 8).

ElA gene products clearly are required for the efficient and timely activation of E2F. The induction of the infection-specific form of E2F was delayed greatly in the absence of ElA gene products. Although the infection-specific activity was detected at 4-6 hr after infection with wild-type Ad5 (Fig. 1), it was not evident until later than $24 \mathrm{hr}$ after infection at a high multiplicity (200 pfu/cell, 10-fold higher than usual) with E1A mutants (Fig. 6A,B). The delay is caused almost certainly by a delay in accumulation of E4 mRNA (Fig. 6C). It seems most likely 


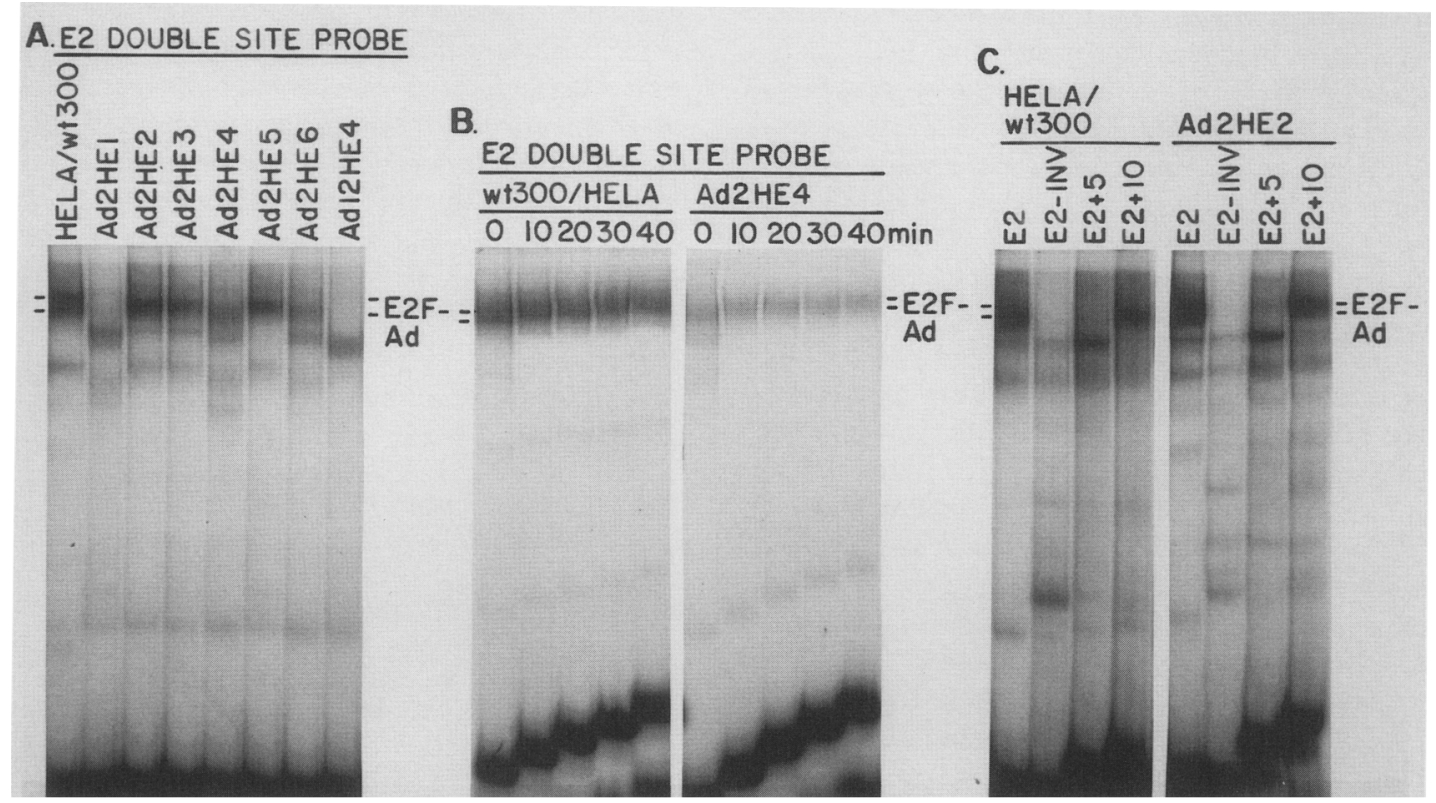

Figure 9. Assay for infection-specific E2F activity in Ad2-transformed hamster embryo cell lines that express E1A, E1B, and E4 genes. (A) Bandshift analysis of E2F-specific activity in extracts of different cell lines that were harvested during exponential growth and assayed using ${ }^{32} \mathrm{P}$-labeled E2 double-site DNA as probe. A cell extract from wt300-infected HeLa cells was included as a control. (B) Off-rate analysis of E2F-Ad complexes formed by activities from wt300-infected HeLa or Ad2HE4 cells. Analysis was performed as described in the legend to Fig. 4. E2F-Ad complexes are labeled. $(C)$ Dependence of E2F binding on the orientation and spacing of E2F sites in E2 DNA. Extracts were prepared from wt300-infected HeLa and Ad2HE2 cells and assayed on the ${ }^{32} \mathrm{P}-$ labeled DNA substrates indicated above each lane. E2F-Ad complexes are labeled.

that the role of ElA gene products is indirect. It functions to activate E4 transcription, whose products, in turn, induce the infection-specific form of E2F activity.

The extended delay in accumulation of infection-specific E2F activity in cells infected with E1A mutants probably explains the failure of Kovesdi et al. (1986, 1987) and Reichel et al. $(1987,1988)$ to detect the activity in cells infected with such mutants.
Is expression of an $\mathrm{E} 4$ product or products sufficient to induce the infection-specific form of E2F? As yet, we cannot be certain. It is clear that the new form of E2F can arise in the absence of E1A, E1B- $55 \mathrm{kD}, \mathrm{E} 1 \mathrm{~B}-21 \mathrm{kD}$, E2A, or E3 gene products (Fig. 2). Furthermore, the process of infection per se is not required because Ad2HE cells that are not undergoing an active infection contain the activity (Fig. 9). The fact that novel forms of E2F ac-

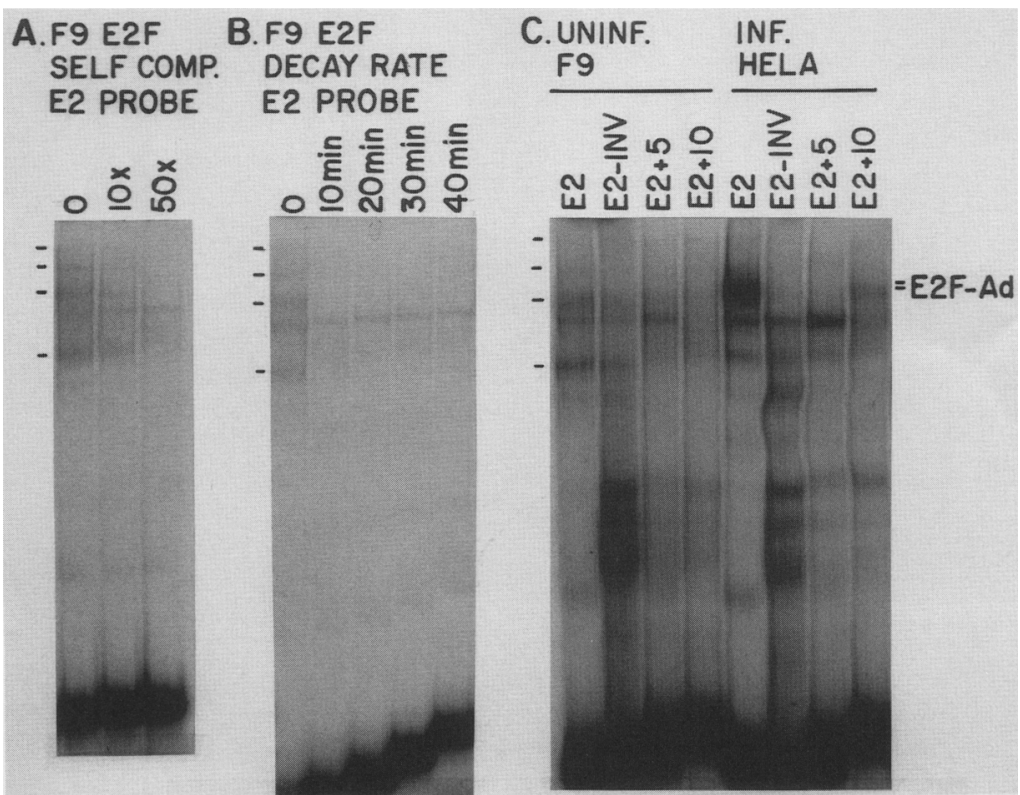

Figure 10. Assay for infection-specific E2F activity in undifferentiated F9 teratocarcinoma cells. (A) Bandshift analysis of extracts prepared from exponentially growing F9 cells assayed using ${ }^{32} \mathrm{P}$-labeled E2 double-site DNA as a probe. Competitions were performed by including in the binding reaction homologous unlabeled E2 DNA at the molar excess over probe DNA indicated above each lane. $(-)$ Sequence-specific complexes. $(B)$ Offrate analysis of complexes formed by activities from wt300-infected HeLa or F9 cells. Analysis was performed as described in the legend to Fig. 4. (C) Dependence of binding on the orientation and spacing of E2F sites in E2 DNA. Extracts from wt300-infected HeLa or F9 cells were assayed on the ${ }^{32}$ P-labeled DNA substrates indicated above each lane. 
tivity are present in dl366 (E4 mutant)-infected cells (Figs. 2C, 3, 4, and 5) raises the possibility that other gene products present in the infected cell can influence E2F activity. Perhaps the d1366-specific E2F activities represent the contributions of another gene product to a modification process, and, as such, are modification intermediates. It is also possible that the dl366-specific forms of E2F result from partial or abnormal activity of a small E4-specific polypeptide that could, in theory, be encoded by the deleted E4 locus in dl366 (Halbert et al. 1985|. Experiments are in progress to determine whether a constitutively active E4 gene, when introduced into cells in the absence of an Ad5 infection, can induce accumulation of the infection-specific form of E2F.

As yet, it is not clear which of the E4 gene products is responsible for the change in E2F activity or how the alteration is brought about. Given the fact that E2F activities from uninfected and Ad5-infected cells share very similar physical properties (S. Hardy and T. Shenk, in prep.), it seems likely that uninfected cell E2F activity is post-translationally modified to generate the infected cell activity. Perhaps an E4 gene product mediates this modification process directly. Alternatively, it could initiate the process indirectly by influencing another gene product that carries out the modification.

The location of the E2F-binding sites suggests that $\mathrm{E} 2 \mathrm{~F}$ is involved in the regulation of E1A and E2 transcription. Its binding sites occur within domains required for optimal transcription of both genes (E1A: Hearing and Shenk 1983, 1986; E2: Imperiale and Nevins 1984; Zajchowski et al. 1985). Kovesdi et al. (1987) introduced a single E2F-binding site as part of an 83-bp sequence upstream of the $\beta$-globin TATA box and found that it stimulated expression of the test gene in a virus-infected cell. Methylation of the E2F-binding site prior to transfection prevented stimulation, suggesting that a single recognition site can stimulate transcription in the appropriate environment.

If the infection-specific form of E2F is important to its role in adenovirus transcription, then one might predict that $\mathrm{E} 4$ gene products contribute to maximal expression or regulation of the E1A and E2 genes. However, E1A and E2A mRNAs accumulate to near normal levels in dl366-infected HeLa cells (Halbert et al. 1985) in the absence of the infection-specific form of E2F. Nevertheless, Goding et al. (1985) have shown that E4 gene products can stimulate the $\mathrm{E} 2$ transcriptional control region in a transfection assay. A role for E4 products in E2 transcription might explain the finding by Murthy et al. (1985) that mutation of one of the two E2F-binding sites upstream of the E2 early start site had no effect on either basal or ElA-induced transcription in transfection assays. Their experiment did not include E4-coded products and, therefore, did not test the infection-specific form of E2F.

We have shown that there are multiple forms of E2F and that adenovirus genes are involved in E2F modification. The variety of E2F activities could allow for multiple functions during several phases of a viral infection. The form that we have studied here is particularly diffi- cult to assign to a function. The infection-specific, cooperative activity that makes the E2F-Ad complexes is found in nuclear extracts from cells 4-6 hr after adenoviral infection, for which transient assays of E2 expression are not a good model. Because the activity is maximal during the late phase of infection and E4 dependent, it is not clear that this infection-specific form is involved in the initial E1A-mediated stimulation of E2 transcription.

\section{Materials and methods}

\section{Viruses and cells}

H5 wt300 (wild-type Ad5; Jones and Shenk 1978), H5dl312 (deletion within E1A gene; Jones and Shenk 1979), H5dl327 (deletion within E3 gene from $\mathrm{H} 5 \mathrm{dl} 324$ and $\mathrm{H} 5 \mathrm{dl} 339$ (deletions within 21 - and $55-\mathrm{kD}$ polypeptide-coding regions of $\mathrm{E} 1 \mathrm{~B}$; Thimmappaya et al. 1982; Logan et al. 1984, respectively) H5dl343 (deletion within ElA gene; Hearing and Shenk 1985), H5dl366 (deletion within E4 gene; Halbert et al. 1985), and H5dI802 (deletion within E2A gene; Rice and Klessig 1985) were purified by equilibrium density centrifugation and, unless otherwise noted, used to infect cells at a multiplicity of 1000 particles per cell $(\sim 20 \mathrm{pfu} / \mathrm{cell})$. HeLa cells were grown in spinner culture using medium containing $10 \%$ horse serum. The 293 (Graham et al. 1977), KB8, and KB16 cells (Babiss et al. 1983), all of which contain and express the Ad5 or Ad2 E1A gene, as well as parental $\mathrm{KB}$ cells, were grown in medium containing $10 \%$ calf serum. Ad2-transformed HE cells (Lewis et al. 1974) express E1 A, E1B, and various E4-coded polypeptides (Johansson et al. 1978; Esche 1982), and were also propagated in medium containing $5 \%$ fetal calf serum. Murine F9 teratocarcinoma cells were obtained from the American Type Culture Collection and propagated in medium containing $5 \%$ fetal calf serum. W162 cells (express E4 gene products; Weinberg and Ketner 1983) and gmDBP cells (express E2A gene product; Klessig et al. 1984) were grown in medium containing $10 \%$ calf serum and used to propagate H5dl366 and H5dl802, respectively.

\section{Oligonucleotides}

Synthetic DNA used for this work was prepared, purified, and labeled as described previously (S. Hardy and T. Shenk, in prep.).

\section{DNA bandshift assays}

Bandshift assays were performed as described previously (Hardy and Shenk 1988). Each reaction contained $3 \mu \mathrm{l}$ nuclear extract or column fraction, 10 fmoles ${ }^{32} \mathrm{P}-$-labeled probe DNA, and $1 \mu \mathrm{g}$ or $5 \mu \mathrm{g}$ of DNase I-digested salmon sperm DNA /30-260 bp in length) for assays using a probe DNA with one or two E2Fbinding sites, respectively. After separation of DNA-protein complexes by electrophoresis in a $4 \%$ polyacrylamide gel (bisacrylamide : acrylamide $:: 1: 20$, unless otherwise noted) in buffer containing $10 \mathrm{~mm}$ Tris- $\mathrm{HCl}(\mathrm{pH} 8), 1 \mathrm{~mm}$ EDTA at $4^{\circ} \mathrm{C}$, gels were transferred to dampened DEAE paper (DE81, Whatmann, Inc.), dried, and exposed to X-ray film. The intensities of the resulting bands were quantified by densitometry of autoradiographs prepared using film preflashed to $0.1 \mathrm{OD}$ and exposed without the use of an intensifying screen. Exposures of up to 1.0 OD were then quantified using a densitometer (Bio-Rad Laboratories, Inc.), which integrated peaks and subtracted backgrounds. 


\section{Off-rate analysis}

The procedure of Fried and Crothers (1981) was employed to determine the dissociation rates of E2F-DNA complexes. Complexes were generated in 10- $\mu \mathrm{l}$ reactions containing $3 \mu \mathrm{l}$ of extract, 10 fmoles of ${ }^{32} \mathrm{P}$-labeled DNA probe, $5 \mu \mathrm{g}$ of salmon sperm DNA, $125 \mathrm{mM} \mathrm{NaCl}$, and $1 \mathrm{mM} \mathrm{MgCl}_{2}$, as described previously (S. Hardy and T. Shenk, in prep.).

\section{Preparation of extracts and chromatography}

Nuclear extracts were prepared from uninfected and Ad5-infected cells according to the protocol of Dignam et al. (1983), with minor modifications (S. Hardy and T. Shenk, in prep.). In addition to phenylmethylsulfonyl fluoride (PMSF), three protease inhibitors were included in extraction buffers $(10 \mu \mathrm{g} / \mathrm{ml}$ leupeptin, $10 \mu \mathrm{g} / \mathrm{ml}$ soybean trypsin/chymotrypsin inhibitor, $0.2 \mathrm{U} / \mathrm{ml}$ aprotinin).

Chromatographic procedures were carried out at $4^{\circ} \mathrm{C}$. Nuclear extract was dialyzed against $100 \mathrm{mM} \mathrm{NaCl}$ in buffer A [ 25 mM HEPES (pH 7.9), $0.2 \mathrm{~mm}$ EDTA, $1 \mathrm{~mm}$ dithiotreitol, $0.1 \mathrm{~mm}$ PMSF, $10 \%$ (vol/vol) glycerol], subjected to centrifugation at $30,000 \mathrm{~g}$ for $10 \mathrm{~min}$ to remove insoluble particulate matter, and loaded (10 ml) onto a cation exchange column (Glass-Pak SP-5PW, $1 \times 7.5 \mathrm{~cm}$, Pharmacia/LKB, Inc.) at a flow rate of 0.5 $\mathrm{ml} / \mathrm{min}$ on an HPLC system (LKB, Inc.). After loading, the column was washed with $100 \mathrm{mM} \mathrm{NaCl}$ in buffer A (5 ml); it was eluted with a 100 to $400 \mathrm{mM} \mathrm{NaCl}$ gradient ( $30 \mathrm{ml}), 400$ $\mathrm{mM} \mathrm{NaCl}$ ( $5 \mathrm{ml}$ ), and a 400 to $1000 \mathrm{mM} \mathrm{NaCl}$ gradient (5 ml), all in buffer A. Fractions $(1.5 \mathrm{ml})$ were collected commencing with the first gradient. A 3- $\mu$ l aliquot of each fraction was analyzed in a DNA bandshift assay.

\section{Acknowledgments}

We thank M. Flocco, J. Song-Nichols, and R. Dickinson for synthesizing DNAs and members of our laboratory for critical commentary on the manuscript. This work was supported by a grant from the National Institutes of Health (CA-8965). S.H. was a predoctoral trainee of the National Institutes of Health (GM-07388), D.A.E. is a postdoctoral fellow of the National Institutes of Health (CA-08210), and T.S. was an American Cancer Society Research Professor.

\section{References}

Babiss, L.E., C.S. Young, P.B. Fisher, and H.S. Ginsberg. 1983. Expression of adenovirus E1A and E1B gene products and the Escherichia coli XGPRT gene in KB cells. I. Virol. 46: 454-465.

Bridge, E. and G. Ketner. 1989. Redundant control of adenovirus late gene expression by early region 4. J. Virol. 63: 631-638.

Dignam, J.D., R.M. Lebovitz, and R.G. Roeder. 1983. Accurate transcription initiation by RNA polymerase II in a soluble extract from isolated mammalian nuclei. Nucleic Acids Res. 11: 1475-1489.

Esche, H. 1982. Viral gene products in adenovirus type 2-transformed hamster cells. J. Virol. 41: 1076-1082.

Freyer, G.A., Y. Katoh, and R.J. Roberts. 1984. Characterization of the major mRNAs from adenovirus 2 early region 4 by cDNA cloning and sequencing. Nucleic Acids Res. 12: 3503-3519.

Fried, M. and D.M. Crothers. 1981. Equilibria and kinetics of lac repressor-operator interactions by polyacrylamide gel electrophoresis. Nucleic Acids Res. 9: 6505-6525.

Goding, C., P. Jalinot, D. Zajchowski, H. Boeuf, and C. Ke- dinger. 1985. Sequence-specific transactivation of the adenovirus Ila early promoter by the viral EIV transcription unit. EMBO J. 4: 1523-1528.

Graham, F.L., J. Smiley, W.C. Russell, and R. Nairu. 1977. Characteristics of a human cell line transformed by DNA from human adenovirus type 5. J. Gen. Virol. 36: 59-72.

Halbert, D.N., J.R. Cutt, and T. Shenk. 1985. Adenovirus early region 4 encodes functions required for efficient DNA replication, late gene expression and host cell shutoff. $J$. Virol. 56: $250-257$.

Hardy, S. and T. Shenk. 1988. Adenovirus ElA gene products and adenosine $3^{\prime}, 5^{\prime}$-cyclic monophosphate activate transcription through a common factor. Proc. Nat1. Acad. Sci. 85: $4171-4175$.

Hearing, P. and T. Shenk. 1983. The adenovirus type 5 ElA transcriptional control region contains a duplicated enhancer element. Cell 33: 695-703.

-1985. Sequence-independent autoregulation of the adenovirus type 5 ElA transcription unit. Mol. Cell. Biol. 5: 3214-3221.

- 1986. The adenovirus type 5 ElA enhancer contains two functionally distinct domains: One is specific for E1A and the other modulates all early units in cis. Cell 45: 229236.

Hemstrom, C., K. Nordqvist, U. Pettersson, and A. Virtanen. 1988. Gene product of region E4 of adenovirus type 5 modu lates accumulation of certain viral polypeptides. I. Virol. 62: 3258-3264.

Herisse, J., M. Rigolet, S. Dupont de Dinechin, and F. Galibert. 1981. Nucleotide sequence of adenovirus 2 DNA fragment encoding for the carboxylic region of the fiber protein and the entire E4 region. Nucleic Acids Res. 9: 4023-4042.

Imperiale, M.J. and J.R. Nevins. 1984. Adenovirus 5 E2 transcription unit: An ElA-inducible promoter with an essential element that functions independently of position or orientation. Mol. Cell. Biol. 4: 875-882.

Johansson, K., H. Persson, A.M. Lewis, U. Pettersson, C. Tibbetts, and L. Philipson. 1978. Viral DNA sequences and gene products in hamster cells transformed by adenovirus type 2 . J. Virol. 27: 628-639.

Jones, N. and T. Shenk. 1978. Isolation of deletion and substitution mutants of adenovirus type 5. Cell 13: 181-188.

. 1979. Isolation of AD5 host range deletion mutants defective for transformation of rat embryo cells. Cell 17: 683689.

Klessig, D.F., D.E. Brough, and V. Cleghon. 1984. Introduction, stable integration, and controlled expression of a chimeric adenovirus gene whose product is toxic to the recipient human cell. Mol. Cell. Biol. 4: 1354-1362.

Kovesdi, I., R. Reichel, and J.R. Nevins. 1986. Identification of a cellular transcription factor involved in E1A trans-activation. Cell 45: 219-228.

. 1987. Role of an adenovirus E2 promoter binding factor in E1A-mediated coordinate gene control Proc. Natl. Acad. Sci. 84: 2180-2184.

Lewis, A.M., Jr., J.H. Breeden, Y.L. Wewerka, L.E. Schnipper, and A.S. Levine. 1974. Studies of hamster cells transformed by adenovirus 2 and the nondefective d2-SV40 hybrids. Cold Spring Harbor Symp. Quant. Biol. 39: 651-656.

Logan, J., S. Pilder, and T. Shenk. 1984. Functional analysis of adenovirus type 5 early region 1B. Cancer Cells 2: 527-532.

Melton, D.A., P.A. Krieg, M.R. Rebagliati, T. Maniatis, K. Zinn, and M.R. Green. 1984. Efficient in vitro synthesis of biologically active RNA and RNA hybridization probes from plasmids containing a bacteriophage SP6 promoter. Nucleic Acids Res. 12: 7035-7056. 


\section{Hardy et al.}

Murthy, S.C.S., G.P. Bhat, and B. Thimmappaya. 1985. Adenovirus E2A early promoter: Transcriptional control elements and induction by the viral pre-early ElA gene, which appears to be sequence independent. Proc. Natl. Acad. Sci. 82: $2230-2234$.

Reichel, R., I. Kovesdi, and J.R. Nevins. 1987. Developmental control of a promoter-specific factor that is also regulated by the ElA gene product. Cell 48: 501-506.

- 1988. Activation of a preexisting cellular factor as a basis for adenovirus E1A-mediated transcriptional control. Proc. Natl. Acad. Sci. 85: 387-390.

Rice, S.A. and D.F. Klessig. 1985. Isolation and analysis of adenovirus type 5 mutants containing deletions in the gene encoding the DNA-binding protein. J. Virol. 56: 767-778.

Sarnow, P., P. Hearing, C.W. Anderson, D.N. Halbert, T. Shenk, and A. Levine. 1984. Adenovirus early region 1B 58, 000dalton tumor antigen is physically asociated with an early region 425 , 000-dalton protein is productively infected cells. I. Virol. 49: 692-700.

Thimmappaya, B., C. Weinberger, R.J. Schneider, and T. Shenk. 1982. Adenovirus VAI RNA is required for efficient translation of viral mRNAs at late times after infection. Cell 31: $543-551$.

Weinberg, D.H. and G. Ketner. 1983. A cell line that supports the growth of a defective early region 4 deletion mutant of human adenovirus type 2. Proc. Natl. Acad. Sci. 80: $5383-$ 5386.

1986. Adenoviral early region 4 is required for efficient viral DNA replication and for late gene expression. 7 . Virol. 57: $833-838$.

Zajchowski, D.A., H. Boeuf, and C. Kedinger. 1985. The adenovirus 2 early EIIa transcription unit possesses two overlapping promoters with different sequence requirements for Ela-dependent stimulation. EMBO I. 4: 1293-1300. 


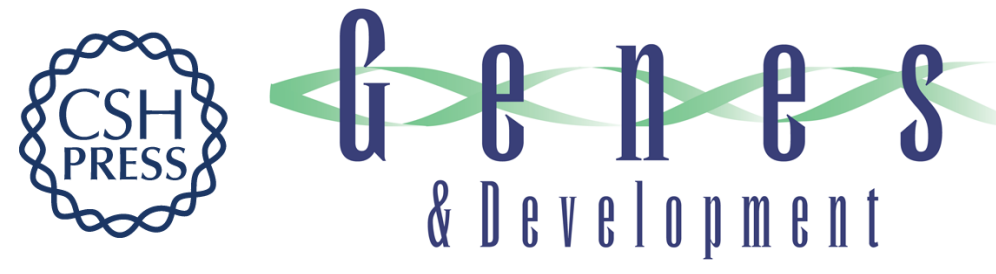

\section{An adenovirus early region $\mathbf{4}$ gene product is required for induction of the infection-specific form of cellular E2F activity.}

S Hardy, D A Engel and T Shenk

Genes Dev. 1989, 3:

Access the most recent version at doi:10.1101/gad.3.7.1062

References This article cites 34 articles, 18 of which can be accessed free at:

http://genesdev.cshlp.org/content/3/7/1062.full.html\#ref-list-1

License

Email Alerting

Service

Receive free email alerts when new articles cite this article - sign up in the box at the top right corner of the article or click here.

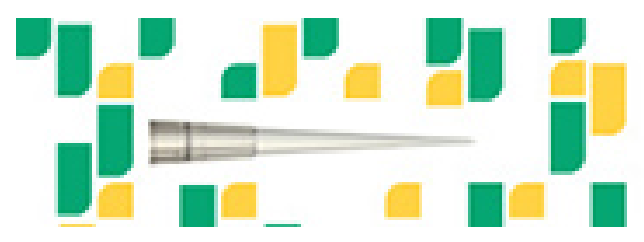

Focused on your science. 